\title{
Comparing the Usefulness of Two Singing Modes to Support Chinese Learning: Karaoke and Dikir Barat in Mandarin
}

\author{
Goh Ying Soon ${ }^{1 *}$ \\ Lee Chai Chuen² \\ Ngo Kea Leng ${ }^{1}$ \\ 1 Universiti Teknologi MARA (Terengganu) \\ 2Universiti Teknologi MARA (Kedah) \\ *E-mail: gohyi141@.tganu.uitm.edu.my
}

Doi:10.5901/mjss.2015.v6n6s2p684

\begin{abstract}
This paper aims to shed some light on the use of two singing modes namely Chinese karaoke and Dikir Barat Mandarin to support Mandarin learning among the non-native Chinese learners. The song can be a very useful tool to enhance learning Mandarin motivation among learners. This study was carried out during a Chinese karaoke competition and Dikir Barat in Mandarin competition which both held at Univerisiti Teknologi MARA (UiTM) Kedah, Malaysia. A self-developed questionnaire was distributed during the two events to gain understanding on the view of the participants on the usefulness in using the two singing modes to support Chinese learning among these non-native Chinese learners. Descriptive and inferential statistics as well as meta-analysis were used to analyze the gathered data. It was found that students agreed that both singing modes are useful to enhance their learning motivation. Thus, singing activities such as Chinese karaoke and Dikir Barat in Mandarin can be used as creative practices in teaching Mandarin as a foreign language in specific and also for other foreign languages.
\end{abstract}

Keywords: Teaching Chinese as a foreign language; singing; learning motivation; karaoke; Dikir Barat;

\section{Introduction}

Singing can be an effective tool for teaching Chinese as a foreign language (Xie \& Lu, 2005). Popular songs are claimed to have a magic on language learning (Wang, 2013). Singing competition such as Chinese karaoke can be used to support Mandarin teaching outside the classroom environment.

Karaoke is a popular tool for language teaching. Karaoke with subtitles enables students to learn the language in an interesting manner (McCall, 2008). Mandarin karaoke singing competition is an innovative method for teaching Chinese to the non-native Chinese learners. Chinese karaoke singing is introduced to the non-native Chinese learners in order to enhance their Mandarin learning motivation.

Dikir Barat is a musical form, native to the Malay Peninsula that involves singing in groups. Using Dikir Barat for Mandarin singing competition is an innovative method for teaching Chinese to the non-native Chinese learners. Dikir Barat in Mandarin singing competition is a combination of Malay culture and Mandarin language group singing which is introduced to the non-native Chinese learners in order to enhance Mandarin learning motivation.

Meta-analysis is the use of statistical methods to combine results of individual studies. It helps to compare results of more than one study. As two studies on singing to buoy up Chinese learning have been done, hence, the objective of this study is to validate the usefulness of two singing modes namely karaoke and Dikir Barat in Mandarin to support Chinese learning. The objective is to clarify that all singing modes are able to buttress Chinese learning.

\section{Literature Review}

There are many literature review supporting that singing can be used as an effective tool to enhance language learning. These set as backbones to support the use of singing activities such as karaoke and Dikir Barat in Mandarin in and outside Mandarin teaching classrooms.

Chinese pronunciation is considered as quite difficult to be mastered by non-native Chinese learners. Music and singing are introduced to the teaching of Chinese as a foreign language to assist the non-native learners to master the 
Chinese pronunciation (Jiang, 1999).

The notion of left brain and right brain tendency for foreign language memory strategy has been widely studied (Jia, 2003). The purpose is to use various methods which include singing to enhance the effectiveness of foreign language learning such as Mandarin. Students are able to use Mandarin songs to memorize Chinese vocabulary, sentences, and etc. through the use of their right brain in singing.

In order to enhance the effectiveness of foreign language instruction, multiple intelligences are believed to have played a vital role (Cui, 2004). Singing which is strongly related to musical intelligence should be utilized to formulate an effective Chinese teaching approach.

Karaoke approach is used for language learning (Hoonchamlong, 2004). Research finding has approved its effectiveness in supporting language learning. Hence, it should be encouraged to use in the teaching of Chinese as a foreign language.

Research findings have also approved that there was a positive relationship between music intelligence and listening as well as speaking skill. (Pei, 2005) Learners with higher musical intelligence performed better than learners with lower musical intelligence. With the use of musical based activity such as singing, it is definitely beneficial to nonnative learners of Chinese.

There were many positive gains in the use of song for Mandarin teaching (Xie \& Lu, 2005). By participating in singing activity, students were able to improve their pronunciation, appreciate the song lyrics and etc.

Goh, Nasirin, Noor Aileen and Raja Mariam (2006) reported that language activities are very relevant for second and foreign language learning. The challenges are placed on the approaches and methods used by the instructors in making these language activities effective for foreign language learning. This is especially true for the use of singing in the teaching of Chinese as a foreign language.

Interest and motivation is the key to the success of foreign language learning (Duan, 2008). Various research findings have approved the motivational aspect of foreign language learning. The use of singing is definitely able to heighten learning motivation and interest among the learners (Goh, 2004). Learners with higher learning motivation are able to perform better compared to learners with lower motivation (Goh \& Ng, 2004).

At the same time, there are many factors that will affect the effectiveness of the use of language activities such as singing on language learning (Goh et al., 2006). Among them, the level of students' attainment of language, the preparedness of students, the winning factors, gender and etc. would have affected students' perceptions.

However, there are also studies showing negative findings on the use of singing for language learning. The results of Racette and Peretz (2007) indicate that the text and the melody of a song have separate representations in memory, making singing a dual task to perform, at least in the first steps of learning. Few words were recalled when singing than when speaking. Furthermore, the mode of presentation whether sung or spoken had no influence on lyric recall in either short or long term recall. Thus, vigilant use of singing in the classroom is called for. Relatedly, the choice of suitable songs is also vitally important. This may negate the positive aspect of the use of singing to support Mandarin learning.

In sum, instructors are called to use singing as a popular tool to boost up the learning motivation in the language learning classroom. As both karaoke and Dikir Barat in Mandarin support language learning in an informal manner, they could be utilized in a good way in the teaching of Chinese as a foreign language.

\section{Research Methodology}

The two studies were carried out during Chinese karaoke singing competition and Dikir Barat in Mandarin competition which both held at Universiti Teknologi MARA (UiTM) Kedah, Malaysia. The research procedure was summarized in Table 1.

Table 1. Research Procedure

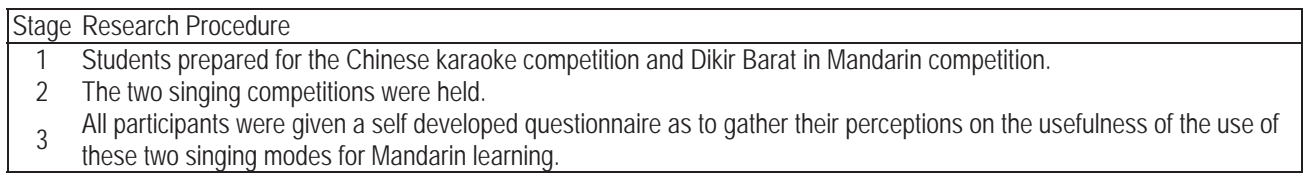

All the participants of the two singing competitions were sampled for this study. The distributions of the samples for the two events were shown in Table 2. 
Table 2. Research Samples of Two Events

\begin{tabular}{|lc|}
\hline Events & Total \\
\hline Chinese Karaoke & 45 \\
Dikir Barat in Mandarin & 233 \\
\hline
\end{tabular}

There were altogether 45 participants for karaoke singing competition while there were 233 participants for Dikir Barat in Mandarin singing competition. All the participants filled up the questionnaires. The data were analyzed by using Statistical Package for the Social Sciences (SPSS) software in order to obtain the information on the descriptive and inferential statistics. The findings were shown in the next section. Meta-analysis was used in this paper. The major reason in selecting this methodology is to have comparisons between the two methods of singing as to validate if there are any significant differences between the perceptions on the differing singing modes to support Mandarin learning. There were several hypotheses have been made for this study, as shown in Table 3.

Table 3. Hypotheses of Study

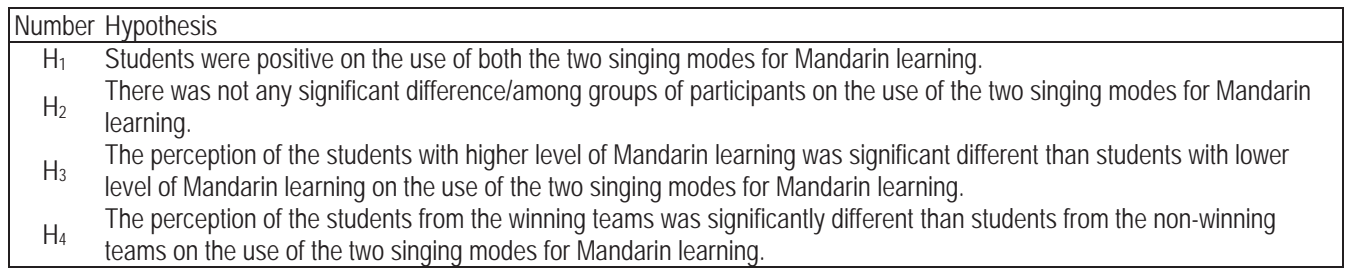

\section{Findings and Discussion}

There were ten questions in this questionnaire. A scale of 5 was used in which 1 was strongly disagreed and 5 was strongly agreed. The perceptions of the students according to groups in the two studies were shown in Table 4.

Table 4. Perceptions of Students According to Groups in Two Studies

\begin{tabular}{|c|c|c|c|c|c|c|c|c|c|c|c|}
\hline \multicolumn{12}{|c|}{ Study 1: Karaoke } \\
\hline Group & Q1 & Q2 & Q3 & Q4 & Q5 & Q6 & Q7 & Q8 & Q9 & Q10 & Overall View \\
\hline 1 Solo & 4.44 & 4.46 & 4.54 & 4.46 & 4.23 & 4.3 & 4.51 & 4.61 & 4.5 & 4.4 & 4.45 \\
\hline 2 Duet & 4.64 & 4.64 & 4.53 & 4.64 & 4.36 & 4.42 & 4.53 & 4.64 & 4.53 & 4.39 & 4.53 \\
\hline Overall & 4.31 & 4.33 & 4.31 & 4.33 & 4.18 & 4.24 & 4.31 & 4.47 & 4.42 & 4.2 & 4.31 \\
\hline \multicolumn{12}{|c|}{ Study 2: Dikir Barat in Mandarin } \\
\hline Group & Q1 & Q2 & Q3 & Q4 & Q5 & Q6 & Q7 & Q8 & Q9 & Q10 & Overall View \\
\hline 1 & 4.33 & 4.28 & 4.28 & 4.14 & 4.06 & 4.31 & 4.22 & 4.36 & 4.39 & 4.19 & 4.26 \\
\hline 2 & 4.27 & 3.93 & 3.97 & 3.97 & 4.03 & 3.93 & 3.97 & 4.13 & 4.07 & 3.97 & 4.02 \\
\hline 3 & 4.24 & 4.2 & 4.24 & 4.16 & 4.24 & 4.16 & 4.16 & 4.32 & 4.32 & 4.36 & 4.24 \\
\hline 4 & 4.04 & 3.96 & 4.08 & 3.8 & 3.64 & 3.96 & 4.08 & 4.16 & 4.2 & 3.96 & 3.99 \\
\hline 5 & 3.64 & 3.59 & 3.5 & 3.59 & 3.41 & 3.59 & 3.55 & 3.59 & 3.64 & 3.68 & 3.58 \\
\hline 6 & 4.04 & 3.96 & 4 & 3.75 & 3.75 & 3.93 & 3.93 & 3.96 & 3.93 & 3.86 & 3.91 \\
\hline 7 & 4.85 & 4.85 & 4.75 & 4.65 & 4.6 & 4.7 & 4.65 & 4.75 & 4.75 & 4.8 & 4.74 \\
\hline 8 & 4 & 3.92 & 3.96 & 4.12 & 3.92 & 3.92 & 4 & 4.04 & 4.04 & 4 & 3.99 \\
\hline 9 & 3.75 & 3.65 & 3.5 & 3.6 & 3.5 & 3.4 & 3.4 & 3.55 & 3.65 & 3.55 & 3.56 \\
\hline Overall & 4.1 & 4.01 & 4.01 & 3.94 & 3.88 & 3.97 & 3.97 & 4.08 & 4.09 & 4.01 & 4.01 \\
\hline
\end{tabular}

For all the items, students have shown positive perceptions (with overall mean of event $1=4.31>4.0$ and overall mean 2 $=4.01>4.0$ ). It showed that the students were affirmative that both Chinese karaoke and Dikir Barat in Mandarin were useful for their Mandarin learning (testing hypothesis $1, \mathrm{H}_{1}$ was accepted).

However, there seemed to be some differences in perceptions between the solo and duet groups for karaoke singing competition and among groups for Dikir Barat in Mandarin competition. T-test was used to validate its significance for singing competition and the F-test was applied to validate its significance for Dikir Barat in Mandarin competition. The 
results are shown in Table 5.

Table 5. Comparing Perceptions of Students According to Groups for Both Events

\begin{tabular}{|lcccclll|}
\hline Study 1 & $\mathrm{N}$ & Std. Deviation & Std. Error & T-value & Sig. & Result & Testing of Hypothesis \\
\hline 2 Groups & 2 & 0.71 & 0.77 & 0.55 & 0.73 & Not significant & Rejected \\
\hline Study 2 & N & Std. Deviation & Std. Error & F-value & Sig. & Result & Testing of Hypothesis \\
\hline 9 Groups & 2 & 0.81 & 0.33 & 0.34 & 0.03 & Significant & Accepted \\
\hline
\end{tabular}

The result showed that there was not any significant difference between the solo and duet groups ( $\mathrm{T}$ ( 2 groups) $=0.55, \mathrm{p}$ $=0.73>0.05$ ). It showed that this study did not confirm that the students have different perceptions on the usefulness of Chinese karaoke to support their Mandarin learning between the solo and duet group. Hence, participating in solo or duet groups did not affect the students' views in the usefulness of using karaoke to support their Mandarin learning. However, the result showed that there was a significant difference among the participating groups ( $F$ (9 groups) $=0.34, p=0.03<$ 0.05). It showed that the participating students have different perceptions on the usefulness of Dikir Barat in Mandarin to support their Mandarin learning. Different groups of students of various campuses were having a divergent perception level on the usefulness of Dikir Barat in Mandarin to support their Mandarin learning. Hence, the results of testing of hypothesis 2 were different.

There were two extraneous factors being studied in this study. The first factor validated in the study was on the level of Mandarin taken. There were 34 students indicating the level of their Mandarin learning. Table 6 showed the level of Mandarin taken by the participants and the means of perceptions. It showed that students from higher level of Mandarin learning were having less positive perceptions on the use of Chinese karaoke to support their Mandarin learning. While for study 2, it showed that students from higher level of Mandarin learning were having more positive perceptions on the use of Dikir Barat in Mandarin to support their Mandarin learning. F-test was used to test if the differences were significantly different.

Table 6. Comparing Perceptions of Students According to Levels of Mandarin Taken in Both Events

\begin{tabular}{|c|c|c|c|}
\hline \multicolumn{4}{|r|}{ Study 1} \\
\hline $\begin{array}{c}\text { Level of } \\
\text { Mandarin Taken }\end{array}$ & Number of Samples & $\begin{array}{l}\text { Means of } \\
\text { Perception }\end{array}$ & Major Findings \\
\hline 1 & 14 & 4.54 & Students from higher level of Mandarin learning were having less positive perceptions on \\
\hline 2 & 14 & 4.20 & the use of Chinese karaoke to support their Mandarin learning. \\
\hline 3 & 4 & 4.20 & \\
\hline 4 & 2 & 3 & \\
\hline Total & 34 & 4.27 & \\
\hline \multicolumn{4}{|r|}{ Study 2} \\
\hline $\begin{array}{c}\text { Level of } \\
\text { Mandarin Taken }\end{array}$ & Groups & $\begin{array}{l}\text { Means of } \\
\text { Perception }\end{array}$ & Major Findings \\
\hline \multirow[t]{2}{*}{1} & 4 & $\begin{array}{l}3.99 \\
3.91\end{array}$ & \multirow{11}{*}{$\begin{array}{l}\text { Students from higher level of Mandarin learning were having more positive perceptions on } \\
\text { the use of Dikir Barat in Mandarin to support their Mandarin learning. }\end{array}$} \\
\hline & $\begin{array}{l}\text { Overall mean for } \\
\text { level } 1 \text { ( } 2 \text { groups) }\end{array}$ & 3.95 & \\
\hline 2 & 2 & 4.02 & \\
\hline & 5 & 3.58 & \\
\hline & 7 & 4.74 & \\
\hline & 8 & 3.99 & \\
\hline & 9 & 3.56 & \\
\hline & $\begin{array}{l}\text { Overall mean for } \\
\text { level } 2 \text { ( } 5 \text { groups) }\end{array}$ & 3.98 & \\
\hline \multirow[t]{3}{*}{3} & 1 & 4.26 & \\
\hline & 3 & 4.24 & \\
\hline & $\begin{array}{l}\text { Overall mean for } \\
\text { level } 2 \text { ( } 2 \text { groups) }\end{array}$ & 4.25 & \\
\hline
\end{tabular}

Table 7. F-Test of Comparison on Students Perceptions According to Levels of Mandarin Taken

\begin{tabular}{|c|c|c|c|c|c|}
\hline Study 1 & $\mathrm{N}$ & Std. Deviation & Std. Error & $\mathrm{F}$ & Sig. \\
\hline 3 levels & 3 & 0.11 & 0.75 & 4.11 & 0.00 \\
\hline Study 2 & $\mathrm{N}$ & Std. Deviation & Std. Error & $\mathrm{F}$ & Sig. \\
\hline 3 levels & 3 & 0.26 & 0.55 & 4.18 & 0.00 \\
\hline
\end{tabular}


In Table 7 the result showed that there was a significant difference among the participating groups according to the level of Mandarin has taken ( $F(3$ levels $)=4.11, p=0.00<0.05$ ). It showed that the participating students have different perceptions on the usefulness of Chinese karaoke according to the level of Mandarin taken. Students with higher level of Mandarin were less positive in viewing that Chinese karaoke supported their Mandarin learning (testing hypothesis 3 , the $\mathrm{H}_{3}$ was accepted). The result showed that there was a significant difference among the participating groups according to the level of Mandarin has taken ( $F(3$ levels $)=4.18, p=0.00<0.05)$. It showed that the participating students have different perceptions on the usefulness of Dikir Barat in Mandarin according to the level of Mandarin taken. Students with higher level of Mandarin were more positive in viewing that Dikir Barat in Mandarin supported their Mandarin learning (testing hypothesis 3 , the $\mathrm{H}_{3}$ was accepted). For both singing modes, the findings were totally reversed even though hypothesis 3 was accepted (see Table 6).

For the second factor, it validated that the study was on the winning aspect. Table 8 showed the means of perceptions of students from the winning teams and non-winning teams. It showed that students from the winning group were having more positive perceptions (mean $=4.55$ ) on the use of Chinese karaoke to support their Mandarin learning compared to the non-winning group (mean $=4.26$ ). While for study 2 , it showed that the non-winning participating students (mean $=4.04$ ) were having slightly higher positive on the perceptions on the usefulness of Dikir Barat in Mandarin than the winning students (mean $=4.03$ ). T-test was used to test if the two findings were significantly different.

Table 8. Comparing Perceptions of Students According to Winning Aspect of Two Events

\begin{tabular}{|c|c|c|c|}
\hline \multicolumn{4}{|c|}{ Study 1} \\
\hline Winning State & $\begin{array}{c}\text { Number of } \\
\text { Samples }\end{array}$ & $\begin{array}{l}\text { Means of } \\
\text { Perception }\end{array}$ & Major Findings \\
\hline \multirow{2}{*}{$\begin{array}{l}\text { 1. Students who won and got prizes. } \\
\text { 2. Students who did not win and get } \\
\text { any prizes. }\end{array}$} & 17 & 4.55 & \multirow{2}{*}{$\begin{array}{l}\text { Students from the winning group were having more positive } \\
\text { perceptions. }\end{array}$} \\
\hline & 28 & 4.26 & \\
\hline \multicolumn{4}{|c|}{ Study 2} \\
\hline Winning State & Groups & $\begin{array}{l}\text { Means of } \\
\text { Perception }\end{array}$ & Major Findings \\
\hline \multirow[t]{5}{*}{ 1. Did not win and get any prizes. } & 1 & 4.26 & \multirow{11}{*}{$\begin{array}{l}\text { The non-winning participating students were having slightly } \\
\text { higher positive perceptions. }\end{array}$} \\
\hline & 3 & 4.24 & \\
\hline & 5 & 3.58 & \\
\hline & 2 & 4.02 & \\
\hline & Overall & 4.03 & \\
\hline \multirow[t]{6}{*}{ 2. Won and got prizes. } & 4 & 3.99 & \\
\hline & 6 & 3.91 & \\
\hline & 7 & 4.74 & \\
\hline & 8 & 3.99 & \\
\hline & 9 & 3.56 & \\
\hline & Overall & 4.04 & \\
\hline
\end{tabular}

The result showed that there was a significant difference between the participating groups according to winning state (t (2 groups $)=2.277, p=0.0237<0.05$ ). It showed that the winning participating students (mean $=4.55$ ) were having slightly higher positive on the perceptions on the usefulness of Chinese karaoke than the non-winning students (mean $=4.26$ ). The winning students did have more positive perceptions than the non-winning teams on the usefulness of Chinese karaoke in supporting their Mandarin learning (testing hypothesis 4, the $\mathrm{H}_{4}$ was accepted). While for study 2, the result showed that there was no significant difference among the participating groups according to winning state ( $\mathrm{t}(2$ groups) $=$ $2.247, p=0.37>0.05$ ). It showed that the non-winning participating students (mean $=4.04$ ) were having slightly higher positive on the perceptions on the usefulness of Dikir Barat in Mandarin than the winning students (mean = 4.03). The winning students did not have more positive perceptions than the non-winning teams on the usefulness of Dikir Barat in Mandarin in supporting their Mandarin learning (testing hypothesis 4, the $\mathrm{H}_{4}$ was rejected). 
Table 8. T-Test of Comparison on Students Perceptions According to Winning Aspect of Two Events

\begin{tabular}{|l|c|c|c|c|c|l|}
\hline Study 1 & T & Df & Sig. & Mean difference & Standard error difference & Result \\
\hline Equal variances assumed & 2.277 & 1 & 0.0237 & -0.01 & 1.6021 & Significant: $\mathrm{H}_{4}$ accepted \\
\hline Study 2 & $\mathrm{T}$ & Df & Sig. & Mean difference & Standard error difference & \\
\hline Equal variances assumed & 2.247 & 1 & 0.37 & -0.01 & 1.6021 & Not significant: $\mathrm{H}_{4}$ rejected \\
\hline
\end{tabular}

\section{Concluding Remarks}

This study has shown that in the whole the students were positive on the usefulness of both Chinese karaoke and Dikir Barat in Mandarin to support their Mandarin learning. It implies that instructors are encouraged to use all kinds of language activities such as singing to engage students in active learning of Chinese as a foreign language.

There is no significant difference in perceptions between the solo and duet groups. It implies that the instructor may use both solo and duet approaches for karaoke singing competition activity. However, there was a significant difference among the groups of participants on the use of Dikir Barat in Mandarin for Mandarin learning. It implies that there are various extraneous factors that may have affected the usefulness of language activities such as singing to support Mandarin learning. The keenness in the use of all kinds of activities has to be balanced up with the gains the students may have in the involvement in all these activities. If not, the efforts in engaging students in all kinds of language activities will be in vain without yielding any substantial benefits.

Students with higher level of Mandarin were less positive in viewing that Chinese karaoke supported their Mandarin learning. It implies that karaoke activity is more useful for students with lower level of Mandarin learning while students in higher level of Mandarin learning should be engaged in more challenging activity. As supported by Racette and Peretz (2007), singing might not be supportive to Mandarin learning for students in higher level of Mandarin learning as they need more authentic and communicative kind of activity. On the other hand, the perception of the students with higher level of Mandarin learning was more positive than students with lower level of Mandarin learning for Dikir Barat in Mandarin. It implies that in the use of any form of language activities, the language ability has to be taken into considerations. Instructors may have organized various types of language activities, but the students involved might not gain maximized benefit. There might be the situation that only students with Chinese background were benefited. Hence, instructors have to put in efforts in diversifying the language activities in order that students of various levels will gain benefits in the participating process.

Lastly, the winning students gained more positive perception than the non-winning teams on the usefulness of Chinese karaoke in supporting their Mandarin learning. It implies that students who won might be more prepared for the competition. Hence, they might gain more through this karaoke activity. Meanwhile, the perception from the winning teams was less positive than the non-winning teams for Dikir Barat in Mandarin competition. It implies that students will gain benefits in the participating process disregards that they will be in the winning positions. The more important part lies in the preparation stages.

Various methods can be used to make karaoke activity more meaningful to support language learning. For instance, Patton (2010) provides suggestions for pairing song selections to supplement lesson plans and activities in a variety of academic disciplines. Instructors may choice songs that pertaining to the lessons that students have. In this manner, it helps to enrich to learning contents. For example, when students study about food in their Mandarin lessons, instructors may introduce songs that are related to food.

In helping students to do a translation of Chinese karaoke lyrics into either Malay or English texts, the instructor may engage students in the use of dictionaries such as desktop dictionary (Goh, 2009), web-based dictionary (Goh, 2011), online Malay dictionary (Goh \& Saiful Nizam, 2013) and etc. Students with hands on experience in the first edition of lyrics texts can then be edited by instructors to improve the accuracy of the translated texts.

In order to strengthen the mastery of Chinese pronunciation as to prepare students in participating in singing competition such as Chinese karaoke, instructors may use various educational technologies to assist them. One of the approaches suggested is the use of Pinyin text to speech system (Goh et al., 2013).

Case study has been carried out on how singing can actually mediate early language development (Wang, 2013). Hence, a study on the use of singing such as karaoke has to be done diligently to validate its effectiveness to support Mandarin learning. Future studies can be done in a qualitative manner to gauge the understanding in depth manner as to enhance the singing approach.

There are other aspects of singing related factors which do not cover in this study. For example, by comparing students with high musical intelligence and low musical intelligence, the students who enjoy singing and students who do 
not like singing and etc. Further study can also be carried out on other modes of singing, for example the use of nursery rhyme and etc. This opens door for further studies in this area.

Singing offers as a creative practice in supporting Mandarin learning. It is certainly encouraged to use both karaoke singing and Dikir Barat in Mandarin in the teaching of Chinese as a foreign language with proper preparation.

In summary, the usefulness of both Chinese karaoke singing and Dikir Barat in Mandarin to support Mandarin learning is definitely positive. The hitch is on how the process of preparing students in the involvement makes the whole process more meaningful and enriching.

\section{References}

Cui, X. H. (崔晓红). (2004). Exploring the use of multiple intelligences for English language teaching. (多元智能理论应用于英语教 学改革的探讨. Journal of Shandong Foreign Language Instruction (山东外语教学), 4, 33-45.

Duan, Y. L. (段艳丽). (2008). Learning interest as the key to the success of foreign language teaching. (激发学生学习兴趣是语文 教学成败的关键). Journal of Neijiang Science and Technology (内江科技), 4, 19-30.

Goh, Y. S. (2004). Tip meningkatkan motivasi belajar bahasa asing. In: Di mana bumi dipijak. UPENA Universiti Teknologi MARA Terengganu, Malaysia.

Goh, Y. S., \& Ng, A. S. (2004). The bumiputra students' attitude in learning Mandarin at UiTM campus Terengganu, Malaysia. Poster presented at the International Colloquium on Language, Attitudes and Education in Multilingual Cities, Brussels, Belgium.

Goh, Y. S. (2009). Youdao desktop dictionary: Learning Mandarin in a painless manner. Electronic Journal of Foreign Language Teaching, 6, 100-107.

Goh, Y. S., Nasirin, A., Noor Aileen, I., \& Raja Mariam, R. B. (2006). Language activities as a platform for second/foreign language learning: Its relevance and challenges. Social and Management Research Journal, 3, 97-112.

Goh, Y. S. (2011). Exploring the use of web-based dictionary in enhancing Chinese writing skill among non-native learners (Yunyong wangshang cidian tigao shuxie nengli chutan). Journal of Research for the Teaching of Chinese as a Foreign Language (Duiwai Hanyu Yanjiu), 7, 54-59.

Goh, Y. S., \& Saiful Nizam, W. (2013). Penggunaan kamus bahasa Melayu ke bahasa Cina dalam penambahan kosa kata bahasa Cina. UiTM Terengganu Journal E-Academia, 2, 8-14.

Goh, Y. S., Saiful Nizam, W., Aileen Farida, M. A., \& Mohd Suhaimi, S. (2013). Pinyin to speech system fostering Chinese speaking skill among non-native speakers of Chinese as a foreign language. UiTM Terengganu Journal E-Academia, 2, 52-60.

Hoonchamlong, Y. (2004). A karaoke approach for language teaching: A case of "learning to read Thai from songs" project. Manusya: Journal of Humanities, 7, 25-40.

Jia, Y. P. (贾䎦萍) (2003). Left and right brain tendency for foreign language memory strategy (左右脑倾对外语记忆策略的影响). Journal of Xibei Industry University (西北工业大学学报, 社会科学版), 3, 51-68.

Jiang, Y. L. (蒋以亮) (1999). Music and pronunciation instruction for the teaching of Chinese as a foreign language (音乐与对外汉语 的语音教学). Journal of Chinese Learning (汉语学习), 3, 15-28.

McCall, W. G. (2008). Same-language-subtitling and karaoke: The use of subtitled music as a reading activity in a high school special education classroom. In Society for Information Technology \& Teacher Education International Conference, 1, 1190-1195.

Patton, L. R. (2010). Karaoke in the Library: Effects on learning, literacy, and social communication. Teacher Librarian, 37, 44-46.

Pei, Z. W. (裴正薇). (2005). Empirical research on the relevance of music intelligence and listening as well as speaking skill. (音乐智 能与英语听说能力相矢性的实证研究). Journal of Nanjing Social Science (南京社会科学), 10, 26-38.

Racette, A., \& Peretz, I. (2007). Learning lyrics: To sing or not to sing? Memory \& Cognition, 35, 242-253.

Wang, K. L. (2013). The magic of popular songs: A case study of music mediated early language development. Canadian Social Science, 9, 130-138.

Xie, X. H. (谢旭慧), \& Lu, G. L. (卢国龙) (2005). The use of song for language teaching (歌曲资源在语言教学中的利用). Journal of Language Teaching and Research (语文教学与研究), 1, 30-40. 